\title{
Law against Corruption: Outcomes of Corruption Counteraction in Russia
}

\author{
Anatoly V. Kirin ${ }^{1}$, Nelly I. Pobezhimova ${ }^{2}$, Yury M. Buravlyov ${ }^{3} \&$ Svetlana A. Sidorova $^{4}$ \\ ${ }^{1}$ State Law Department, Administration of the President of the Russian Federation, Moskow, Russia \\ ${ }^{2}$ Higher School of the Russian Federation, Moskow, Russia \\ ${ }^{3}$ Department of Constitutional and Administrative Law, Private Educational Institution "NIKS", Moskow, Russia \\ ${ }^{4}$ Department of Theory of Law and Administrative Legal Disciplines, Ryazan State University named after S.A. \\ Esenin, Ryazan, Russia \\ Correspondence: Svetlana A. Sidorova, Department of Theory of Law and Administrative Legal Disciplines, \\ Ryazan State University named after S.A. Esenin, Ryazan, Russia. E-mail: umb-50@mail.ru
}

Received: November 29, 2019

doi:10.5539/jpl.v13n2p220

\author{
Accepted: February 12, 2020 \\ Online Published: May 27, 2020 \\ URL: https://doi.org/10.5539/jpl.v13n2p220
}

\begin{abstract}
The article is devoted to the scientific analysis of efficiency of legal and organizational measures taken by the state to counteract corruption in the Russian Federation. The authors critically evaluate their effectiveness, pay attention to methodological gaps in choosing means and methods of fighting this scourge. They also substantiate the necessity of rigorous differentiation of legal liability for corruption offences depending on official capacity of the offender and the area of state activity or social life that is encroached by the offender.

Examining the genesis of the state's reactions to the scope and danger of the present problem, it can be said that formal acknowledgment of corruption hazard in society and public service in particular has come after a considerable delay only when this phenomenon took a form that endangered foundations of the society and the state itself and when the global institutions paid attention to a high level of corruption in the Russian Federation.

The article studies the impact of law as the most powerful instrument against corruption, the most typical and major drawbacks of legal acts and the degree of their preventive action. The authors emphasize introduction of supplementary restrictions and prohibitions in the civil service system and economy sector. The article draws attention to intensification of criminal repressions for the most dangerous crimes such as bribery, corruption intermediation and others.

The conducted analysis of measures taken by the state and assessment of their efficiency by the public consciousness allow us to formulate a scientific hypothesis on the reasons and conditions that have determined poor performance of counteracting corruption. The authors point out some attempts to mobilize the civil society to fight corruption; however the government failed to significantly reduce its level.

It is postulated that at present there is a necessity to refine the anti-corruption strategy, to optimize the balance between enforcement measures and stimulation as well as motivation of law-abiding behavior of public servants and others involved in public legal relationships, especially of those related to at-risk group. It is of great significance to intensify state and public control over certain activities such as government and public procurement, budget expenditures, the use of material resources, and others.
\end{abstract}

Keywords: corrupt behavior, corruption, corruption offence, counteraction corruption, reasons for civil servants' corrupt behavior

\section{Introduction}

According to the annual ratings published by the international non-governmental organization Transparency International, Russia is currently ranked from $146^{\text {th }}$ to $138^{\text {th }}$ in the world on its corruption perceptions index. We believe that there is an informed judgment that Corruption Perceptions Index is a self-fulfilling prophecy ${ }^{1}$ as,

${ }^{1}$ Danielle E. Warren William S. Laufer (2010) Are Corruption Indices a Self-Fulfilling Prophecy? A Social Labeling Perspective of Corruption. Retrieved from https://ru.wikipedia.org/wiki/Список_стран_по_индексу_восприятия_коррупции (reference date: 06.10.2019). 
being constantly cited in mass media, it influences inhabitants' perception of corruption and reduces opportunities for economic growth. Thus, associate professor of New York University in Abu Dhabi Georgi Derluguian points out that it is extremely difficult to measure the level of corruption and ratings shouldn't be fully trusted. He says that according to all Transparency International's ratings Iceland had been taking leading positions until it was found out about the engagement of several ruling families with banks and the two main political parties. This example reveals inadequacy of the Index. ${ }^{2}$

The situation in our country hasn't improved compared with the Soviet Union and even more with Denmark, New Zealand, Finland, Sweden, Switzerland, Singapore and some other counties that are the leaders on anti-corruption index. Of course, these countries' anti-corruption enforcement experience is of great value not only from the view of scientific and cognitive interest, but it also allows to avoid mistakes in overcoming the given phenomenon in Russia taking into account best foreign expertise.

\section{Methods}

Various methods were applied in the process of studying the combination of factors that have determined low efficiency of overcoming corruption in the Russian Federation and its devastating impact. From the perspective of general approach to the analysis of the problem of corruption the authors used dialectical method and systematic approach. Analyzing specific issues such methods as logical method, analysis and synthesis, correlation were applied. The method of comparative law was used in the process of examining foreign expertise in countering corruption.

\section{Results and Discussion}

In the Russian Federation awareness of menace of corruption, as well as necessity of a resolute struggle with this phenomenon that demoralizes foundations of the society and causes great damage to the country's economy and the rule of law, has come after a considerable delay only when corruption penetrated into all spheres of public and social life, and have already ceased to be the subject of disapproval among a large part of the Russian society. An exception is a number of high-profile cases that were given publicity in mass media or were debated a lot on the Internet. The government has made certain anti-corruption efforts, but without differentiating them as to liable parties and spheres of state and social life. So it can be considered a serious methodological gap. So called household and white-collar corruption are hardly the same thing, therefore, ways of combating these types of corruption should be adequate to the level of social danger of its every specific form.

A definite contribution to counteracting corruption is made by the legal science. Its representatives express different or even completely opposite judgments and opinions on government corruption, reasons, and methods of fighting against this anti-social phenomenon of the reality. In Russia overcoming corruption manifestations in public service as an important national objective, has started to embody also because international organizations turned the country's leadership attention to the high level of government corruption in the Russian Federation that seriously impedes economic and social reforms in this country. However, the Russian society has appeared to be rather unprepared for a hard-line struggle against corruption. Thus, regular citizens do not disapprove "gratitude" to a doctor for medical aid, "gift" to a kindergarten teacher, "donations" to a school teacher, and other dubious ways of solving some vital issues. It occurs when a person desires to get an immediate result realizing the fact of violating law and moral prohibitions.

Modern humanities, as well as legal science, consider corruption from the view of different aspects of its manifestation such as legal, political, economic, socio-psychological, and others.

In Public International Law definitions of corruption are included in several international acts, such as United Nations Convention of 2003 and Council of Europe Convention of 1999. ${ }^{3,4}$ Scientists' endeavors to conceptualize such a complex phenomenon as corruption and provide a universal (for all real-life situations) definition of the notion appeared to be counter-productive. However, it doesn't mean that this work should be stopped. On the contrary, it would be quite useful to enhance efforts in this regard. It seems that one could try to formulate a definition with reference to specific kinds of corruption: household corruption, government corruption, corruption in the sphere of state and municipal services, in business, and so forth. We suppose that certain areas of law which regulate disciplinary, administrative, criminal, and financial liability could be taken as the basis of differentiation of corruption acts. One should probably start with formulating political and legal,

\footnotetext{
2 Grigorjev A. (2010) Corruption - 2010. Analysis and perspectives. Voice of America Retrieved from https://ru.wikipedia.org/wiki/Список_стран_по_индексу_восприятия_коррупции. (reference date: 06.10.2019)

${ }^{3}$ United Nations Convention against Cormution of 31 October 2003.

${ }^{4}$ Council of Europe's Criminal Law Convention of Corruption of 27 January 1999.
} 
socio-psychological or purely economic definition of this complex, ever-altering phenomenon of legal and social reality.

The analysis of the legal definition, stated for purposes of the Federal law of the Russian Federation On Corruption Counteraction that is often referred to by the authors, reveals its purely criminal focus which in fact is reduced to enumeration of penal acts. The weak point of this approach is that the law enforcer is granted wide freedom of sole discretion expressed in the following wording: "any other individual's unlawful use of his or her official position". It may be interpreted as containing corruption risks. In order to characterize a certain act as corruption, one must also find out the offender's purposes that, according to the mentioned legal norm, are expressed in gaining benefit in terms of money, valuables, other property or property related services. But there are also intangible services that are considered to be an implicit form of "gratitude" to the official but formally may be regarded as friendly attitude. Both daily life and law enforcement practice have proved frequently that any attempt to enumerate all possible corruption incidences while defining the notion are doomed to failure from the very start.

The theory and law enforcement practice include such anti-corruption principles of primary importance as legality, equality under the law, presumed knowledge of the law, presumption of innocence, inevitability of legal responsibility, liability for an act committed with quilt, just retribution for socially dangerous offences.

Numerous research papers that currently exist ${ }^{5,6,7}$ do not interfere with attaining the truth, making new scientific generalizations or proposing hypotheses adequate to the altering nature of corruption. On the contrary, they bring the researchers closer to understanding the phenomenon of corruption in various forms of its manifestation.

The real awareness of menacing proportions of corruption and the degree of its danger to the public were initiated by the Russian President's Decree of 19 May, 2008, No. 815 On Anti-corruption Measures ${ }^{8}$ by which an Anti-Corruption Council under the President of the Russian Federation was established. The next stage was adoption of National Anti-corruption Plan of 31 July, 2008, Pr. 1568 that put forward a succession of similar acts. In the Russian Federation, as the document states, for the most part only legal and organizational bases of counteracting corruption have been established and are functioning. There is also a considerable anti-corruption capacity behind the legislation of the Russian Federation that regulates the issues of public service.

At that time the necessity of extensive anti-corruption campaign was substantiated by the fact that despite undertaken measures corruption was an inevitable result of excessive administrative regulation on the part of the government that seriously precluded proper functioning of all public mechanisms and discouraged social reformations and efficiency improvement of the national economy. As it is noted further, corruption causes great anxiety in the Russian society and mistrust towards State institutions, it generates a negative image of Russia on the world stage and is fairly considered to be one of the security threats to the Russian Federation. We should agree with the conclusions made about those negative consequences of corruption. But it will be wrong to resolve the reasons of corruption just into the negative impact of the state because, from our viewpoint, it has no scientific basis and appears to be an unconvincing argument.

Nevertheless, more and more efforts were applied to counteract corruption and an important event has become adoption of the Federal law of 25 December 2008, No 273-FZ On Corruption Counteraction ${ }^{9}$. It is the core document that has enabled adoption of the package of anticorruption bills that is still being supplemented, especially on the part of itemization and attachments necessary for elimination of defects revealed in the law enforcement process.

This process can be viewed in stages in the following way. In 2010 by Decree of the President of the Russian Federation of 13 April 2010 No 460 the National Anti-corruption Strategy and the National Anti-corruption Plan for 2010-2011 ${ }^{10}$ were approved. The analysis of this document has shown that it enumerates mainly the same destructive consequences of corruption as the preceding legal acts did. So, we come to the conclusion that the past two years after termination of the specified plan did not bring measurable results of counteracting

\footnotetext{
${ }^{5}$ Komarova, A. (2009). Overcoming Corruption - main condition for legal state establishment Interdepartmental scientific publication. Moscow, Vol. 1.

${ }^{6}$ Kurakin, A. (2016). Anti-corruptional policy of Singapore. Administrative and criminal legal aspects: Monograph. M.: UNITY-DANA: Law and Rights.

7 Artemjev, A. (2011) Corruption anthropology: Monograph. Sankt Petersburg: In-ta.

${ }^{8}$ Collection of Legislative Acts of the Russian Federation, 2008, №1, Article 2429.

${ }^{9}$ Collection of Legislative Acts of the Russian Federation, 2008, № 52 (Part 1). Article 6228.

${ }^{10}$ Collection of Legislative Acts of the Russian Federation, 2010, № 16. Article 1875.
} 
corruption.

During the following years adoption of normative legal acts entitled as National Anti-corruption Plan continued, but they commonly had a short-term effect, and this gave an illusion of an easy triumph over corruption or initially just simulated counteracting it. It is sufficient to mention only some documents of this kind adopted in the recent years. They are Decree of the President of the Russian Federation of 1 April 2016 №147 On National Anti-corruption Plan for 2016-2017 ${ }^{11}$ and Decree of the Head of the Government of 29 June 2018 № 378 On National Anti-corruption Plan for 2018-2020 ${ }^{12}$. The necessity of their adoption arises from article 5, chapter 1, paragraph 1 of the Federal law of 25 December 2008, № 273-FZ “On Counteraction Corruption”. Without denying the importance and especially expediency of adoption of these documents, we point out high degree of their similarity, poor targeting of planned activities, and, more importantly, lack of personal responsibility. Meantime, it should be noted that the plan being a document of practical character is supposed to contain specific instructions, precise wordings, it should set implementation deadlines for proposed activities and those responsible for them as well as forms of supervision over its performance. In fact, everything is reduced to receiving field reports on the cases of corruption in a certain region or public body. Accordingly, information in these reports seems more or less satisfactory. It is logical to assume that there are more people willing to put a gloss on the reality that those who are interested in putting themselves in an unfavorable light.

Structurally adopted anti-corruption plans include, as a rule, measures aimed at problem solving and contain instructions to the Government of the Russian Federation that oblige it and other entities to submit reports on performance results of proposed measures within the deadline.

Thus, the primary objective proclaimed in the National anti-corruption plan for 2016-2017 was the improvement of mechanisms of preventing and identifying conflicts of interest, the state officials' expenditure control, intensification of anti-corruption measures in government and municipal procurement, extension of the use of international collaboration mechanisms for detecting and recovery of corrupt officials' assets, fostering public intolerance towards corruption acts.

The National anti-corruption plan for 2018-2020 has got a number of distinctions; it is structured according to objectives and contains the following new provisions:

1) in the context of legislation improvement law enforcers are assigned to elaborate drafts of federal laws on expanding the scope of application of bans, restrictions and requirements imposed on purposes of counteracting corruption; of improving anti-corruption standards, making amendments in legislation concerning supervision over expenditures of individuals suspected or accused of corruption offences; to consider reasonability of introducing administrative liability for violation of counteraction corruption requirements of the Russian legislation related to preventing and resolving conflicts of interest;

2) on improving responsibilities of persons holding public positions and civil service positions in federal and regional authorities. New concepts and terms have been introduced such as "force majeure circumstances that do not constitute criminal offences"; "minor offences" in corruption-related cases; "mitigating and aggravating factors" that can be considered as some relaxation of liability of perpetrators;

3) insofar as it refers to methodological support of corruption counteraction the Plan prescribes to approve assessment methodologies for projects of counteraction corruption practices among the federal government authorities; for conduction of sociological researches with the purpose of assessing levels of corruption within the constituent entities of the Russian Federation; for the work aimed at identification of personal interest of public and municipal officials in the procurement process;

4) there was an intention to draw up proposals on making amendments in the Russian Federation legislation that provide adoption of modal additional professional programs on the issues of corruption counteraction; development of students' expertise that allows to generate intolerance towards corruption behavior; to work out a set of educational activities aimed at fostering public intolerance towards corruption acts as well as improving efficiency of anti-corruption education.

It can be positively viewed that The Plan contains certain mandates to the federal executive authorities. For example, the Ministry of Labour of the Russian Federation together with the Office of Public Prosecutor of the Russian Federation are entrusted to conduct a survey of application of legislation with respect to prevention and resolution of conflicts of interest. It is also prescribed to consider the possibility of involvement of concerned

\footnotetext{
${ }^{11}$ Collection of Legislative Acts of the Russian Federation, 2016. № 14. Article1985.

${ }^{12}$ Collection of Legislative Acts of the Russian Federation2018. № 27. Article 4038.
} 
scientific organizations and universities in carrying out anti-corruption assessment of legal acts.

Imposing a duty on a special working group as to exercising control over the implementation of activities for the respective period is worth appreciation. We hope that the performance of the current National Plan will be more successful than of previous corresponding documents. Unfortunately, this issue has got little publicity because obtained results are not officially reported. Under such circumstances it becomes a problem to generate public support towards anti-corruption efforts of the government since it, to a great extent, determines success or failure in such a difficult struggle against corruption in the Russian Federation.

At present in relation to counteracting corruption the government prefers strengthening of legal administrative and criminal sanctions, application of disciplinary measures, imposing additional particular responsibilities on public officials and other individuals, introduction of new restrictions, bans and requirements aimed at corruption counteraction. The given conclusion results from the analysis of the Anti-corruption Strategy and law enforcement practice. However, dealing with this problem one should have gone further and tried to differentiate prohibitive measures in compliance with the position of state or local public officials or employees of other public authorities, organizations and establishments.

Along with penal sanctions more consistent has become application of restorative justice measures connected, first and foremost, with property damage compensation caused by unlawful acts of perpetrators. Compensation has recently become an obligatory condition for mitigating punishment or even total exoneration from criminal responsibility that is particularly noticed in the sphere of criminal liability of corrupt officials. However, attitude to this sort of "humanity" towards embezzlers of public funds and other corruption acts in the Russian society is quite ambiguous.

It seems that in the listed documents there are some rather important but neglected aspects that impede an aggressive fight against corruption. Thus, considering social and economic aspect of the problem one must draw the reader's attention to stratification of the Russian society into a small strata of citizens possessing the most part of Russia's national wealth, and the major group of citizens living at or below the poverty line. It can be considered as a factor of acute social tension and a favorable environment for corruption. In modern Russia this problem has reached dangerous proportions that threaten the country's national security, which is officially admitted in the documents ${ }^{13}$. The President of the Russian Federation defining social and economic situation in his Message of 2019, was repeatedly appealing to the problem of poverty in Russia that indicates understanding and, what is more important, the intention to help our citizens overcome the condition of degrading treatment. However, despite some efforts it is still impossible to eliminate poverty, and the state cannot or just doesn't want to fight against inequality. But in every aspect, it is extremely dangerous to leave the situation as it is.

We believe that dealing with corruption it is advisable to accentuate differentiation of repressive measures giving severe punishment only to those who commit serious crimes, neglect cynically interests of citizens, society and the state. On the contrary, individuals who admit to society their guilt, express effective remorse for the offence and compensate material damage should be given a chance to overcome their mistakes. As far as corruption refers mostly to a material category, any opportunity for gaining material benefits must be excluded so that it will become useless to commit corruption acts. One of effective measures can be considered total forfeiture of illegally acquired property and other goods as well as partial renunciation of presumption of innocence on corruption offences dealing with the issues of legitimacy of acquired wealth. A successful outcome can be expected from absolute ban on conditional sentence and parole of guilty persons for corruption offences.

One more aspect refers to disavowal of the principals of equality under the law and equal protection. As long as the state protects only the rights of the Russian establishment and patronizes only the privileged ones, the situation in our country will not change and is likely to get even worse. It is still impossible to rely on change in citizens' attitude towards this prejudicial tradition of problem solving through giving "gratitude" to the right men. We also cannot count on a wide public support in counteracting corruption. Thus, the Sicilian mafia was immortal as long as people arose to fight against it. We believe that this historic example may be quite instructive also for Russia, as it is the country with its identity, which is able to resolve the most challenging economic and social problems, to provide defense of its sovereignty not only by means of military force, but with the help of its great international prestige and ever-increasing international influence. In this respect corruption counteraction appears to be quite a realistic objective.

\footnotetext{
${ }^{13}$ Decree of the President of the Russian Federation of 31 December 2015 № 683 On National Security Strategy of the Russian Federation”. Retrieved from www.pravo.gov.ru
} 


\section{Summary}

The conducted analysis of legal and scientific papers taken to prepare the given article enables the authors to formulate certain conclusions.

One should positively view formal awareness of danger of corruption prevalence in the state and importance of political will in the process of counteraction this phenomenon, and undertaken efforts to generate intolerance towards corruption acts not only in citizens' everyday life but, more importantly, in civil servants' activities.

A definite achievement is meant to be the development of the anti-corruption legal basis appropriate to practical application, adoption of measures that restrict opportunities of committing corruption offences in public service.

At present legal regulatory institutions are considered to be the principal anti-corruption instrument comprising not only punitive sanctions but also measures that stimulate public servants and other officials to behave in compliance with the law.

\section{Conclusions}

The analysis of measures undertaken by the government on the purpose of counteracting corruption has brought some positive results. They are: mobilization of the society's active forces for overcoming the problems of corruption in Russia, public authorities (mainly law-enforcement authorities) are charged with complete revealing of corruption acts and a firm struggle against this scourge of corruption, legal preconditions have been created to achieve resolution of this objective, facts of certain corruption acts have been given publicity and those responsible have been held to account regardless of their official position and social status.

However, it becomes clear that anti-corruption efforts should be accumulated and aimed on a long-term work in comprehensive corruption counteraction and uncompromising struggle against it.

\section{Copyrights}

Copyright for this article is retained by the author(s), with first publication rights granted to the journal.

This is an open-access article distributed under the terms and conditions of the Creative Commons Attribution license (http://creativecommons.org/licenses/by/4.0/). 